\title{
The Impact of Applying AAOIFI in Islamic Banks. Case Study in Iraqi Islamic Banks - Part II -
}

\author{
Dhiaa Al Deen ALAZZAWI, PhD, Professor Ileana NIȘULESCU-ASHRAFZADEH, PhD
}

Bucharest University of Economic Studies, Romania

\begin{abstract}
The objective of this research is to study the impact of applying the AAOIFIs in Islamic banks, while referring to the impact of applying the AAOIFIs in Arab countries, the focus being on the Iraqi Islamic banks. The major responsibility of the AAOIFIs is to guarantee that accounting methods comply with Sharia - Islamic law, which is only used by a few financial institutions in Islamic countries especially Islamic banks. The AAOIFIs are an enchanting prospect coming from the holy scripts.

The researchers obtained the data for the study through a questionnaire prepared for this purpose, distributed to 68 workers in the field of Islamic banks. The researchers received 52 responses from several Islamic banks. The study concluded with the set of results that Islamic banks are seeking for the profitability without increasing the security for their deposits or attracting more investors, and the customers of Islamic banks are seeking for "legal benefits" by their investment.

The study led to the conclusion that the adoption of the AAOIFIs in Islamic banks will not help attracting foreign investments. The study suggested there is an urgent and actual need to adopt and implement the IFRSs instead of the AAOIFIs within the sample of the study and include other institutions with a similar environment like Islamic banks.
\end{abstract}

Key terms: AAOIFI, Shariah, Murabaha, Iraqi Islamic banks

JEL Classification: M40, G21

To cite this article: Dhiaa AI Deen Alazzawi, lleana Nișulescu-Ashrafzadeh, The Impact of Applying AAOIFI in Islamic Banks. Case Study in Iraqi Islamic Banks (II), CECCAR Business Review, No 10/2021, pp. 51-59, DOI: http://dx.doi.org/10.37945/ cbr.2021.10.07

\section{O Islamic banks}

Nowadays, the world is witnessing a qualitative shift in the field of Islamic banking. Despite the fact that the conventional banks are based on interest and control the economy and the liquidity in the world, Islamic banks that took the emblem of verse [That is because they say, "Trade is [just] like interest." But Allah has permitted trade and has forbidden interest. So, whoever has received an admonition from his Lord and desists may have what is past, and his affair rests with Allah]. Through this, Islamic banks have become realistic and possess an objective economic thinking, and these banks have formed a tangible and effective reality to solve many economic and social problems that made the society suffer in Islamic and non-Islamic countries.

Islamic bank is a financial institution which is based on executing partnership contracts which involve a commitment to practice Sharia-permitted banking business on a non-interest basis, neither paying nor receiving interest, and according to the banking transaction patterns that does not conflict with the provisions of Islamic Sharia, whether in the area of accepting deposits or providing any banking or financial investment services. 
Islamic banks have proven over nearly 30 years of operation in the Gulf and the Muslim countries, that they have been successful in developing banking business according to the Islamic law provisions, and this industry have had a serious contribution to investment projects, financing and economic development.

\section{The impact of applying the AAOIFIs in Islamic banks}

Applying the AAOIFIs has many impacts, some of them are to improve accounting and auditing, and others are to encourage Islamic financial institutions to take into consideration the international standards and practices which comply with Islamic Sharia rules. Also, one of the main reasons is the uniqueness of Islamic banking and financial operations, in terms of the theoretical and practical basis, which distinguishes it from the conventional practices. Moreover, the AAOIFI standards provide the necessary tools for the Islamic transaction's requirements, and help providing an honest and fair presentation of the financial position of Islamic banks.

The AAOIFI standards are based on special features that distinguish Islamic banks from the conventional banks. In order to increase the confidence of shareholders and other users of the financial statements of Islamic institutions, AAOIFI has been ensuring that they follow the principles of the Islamic law Sharia, representing the general direction in which these institutions have been progressing and containing an all-comprehensive set of standards.

The objectives of Islamic bank are abolishing the existing problems in society. For example, the most important need of the Islamic community is the existence of an integrated banking system that works in accordance with Islamic law to preserve and invest the wealth. There are several objectives for Islamic banks that can be explained below:

$\checkmark$ Financial objectives. It is a reconciliation of concerns regarding profitability, liquidity and safety, and based on the fact that Islamic banks are primarily Islamic financial institutions that perform financial intermediation, and their business model is based on the principle of participation. Therefore, we find many financial objectives that reflect the extent of the success of these Islamic institutions in fulfilling this role of Sharia provisions.

$\checkmark$ Money investment is a process of financial intermediation. This is considered one of the most important objectives of Islamic banking. Investment is the main pillar and then main focus of Islamic banking to achieve profits, whether for depositors or shareholders. There are many Sharia investment formulas that the banks are using for the purpose of achieving social benefit.

$\checkmark$ Profit making. Profits are considered one of the most important aims set out by banks, or any business for that matter. Profits generated from banking activities are distributed to those who are entitled, i.e. shareholders and depositors. Naturally, any increase in the profits of a bank leads to an increase in the market value of its shares. Islamic banks are one of the Islamic institutions whose main function is to achieve profits to help them compete in the global banking market. Failing to do so means they lose their competitiveness in the global banking markets.

$\checkmark$ Banking services. The success of Islamic banks in providing high quality banking services to their clients will eventually work on attracting more clients to them. Moreover, following AAOIFI standards would distinguish them from other conventional banks, since all operations are performed within the framework of the Islamic law.

$\checkmark$ Deposit protection. One of the most important factors for the success of Islamic banks is the level of trust from depositors in them. And one of the most important factors of trust in banks is the provision of cash liquidity always to meet all the possible withdrawals from deposits at any time. This is why it is very important for Islamic banks to choose a successful safe projecting order to achieve profits and provide the necessary liquidity and protection to depositors.

\section{- Islamic banks standards (standard No. 8 Murabaha)}

Islamic banks are applying standards which consist of 85 paragraphs in their financial statements in order to meet the common information needed by the main users of those statements in the area of accounting. These standards can be applicable to all Islamic banks in any country in the world (AAOIFI, 2002). 
Al-Askar (2005) argues that the financial statements should contain several important facts that have an effect on the ability of the user to benefit from them when the client is making decisions for investment and utilizing funds, according to the principles of Islamic law Sharia. In the following part, the researcher is going to talk about one of the most important Islamic standards that is mostly used in Islamic banks, namely Murabaha "sale contract".

The Arabic word ribh, which means profit or gain, is the source of the word Murabaha. More precisely, Murabaha means buying and selling with a marginal profit. It is the most widely used Islamic banking form of contracting. It is originally a sale contract, and it is used today as a contract between the clients and the bank, in which the bank is asked to buy a specific product for a client. So first, the bank purchases the product and possesses it then sells it to the client in a separate contact at a predetermined mark-up price. Both the cost of the product and the bank's predetermined mark-up would be disclosed and known to all the contracted parties. The bank's profit is represented by the mark-up, which is the reward for the risk inherent in the financing; in the case where the customer refuses to buy the product, the bank bears the loss. (Ben Arab and Elmelki, 2008)

Moreover, the sale should include the terms of payment, either by instalments or on a lump sum basis. Murabaha consists of three components:

$\checkmark$ The bank and the clients are promising the buying and selling of goods or other services that both agreed on.

$\checkmark$ The bank buys the goods or services from the third part by an order from the clients.

$\checkmark$ The bank charges a mark-up price for the goods and services and sells them to the clients at credit. (Ben Arab and Elmelki, 2008)

This Murabaha standard contains 18 paragraphs. They apply to assets available for sale. It deals with several aspects such as the expenses, revenues, gains, and losses related to an asset. This shall be applied in Islamic banks when they purchase these assets exclusively from their own funds, from the pool of commingled funds comprising unrestricted investment accounts and the Islamic bank's own funds. (AAOIFI, 2002)

Murabaha is the base of the activities of the Islamic banks such as purchasing goods and then selling them to the clients who seek those goods; in the end these selling procedures take place with an agreed profit over the cost price along with postponed payment (Ahmed, 2014).

The discussion that took place on Murabaha is perhaps one of the most detailed and complex debates in Islamic contract law and Islamic economic history. Therefore, Murabaha is a typical example that can help to understand one of AAOIFI's standards, the economic issues and the reasoning behind its application which is to come up with solutions to meet the Islamic law. Although Murabaha is a credit solution for those clients in need of a specific commodity who cannot afford to make cash payment, its dominance represents the failure of Islamic banks to respond to the full range of financing needs of those seeking external finance that is in accordance with Islamic values.

Another shortcoming is in the field of development. The tendency of Islamic banks is to use debt-like instruments which departs from the goal of contributing to the development of their countries. There is a clear need for the adoption of other less debated modalities of financing that also encourage long-term investments.

\section{The Iraqi banking activities for Islamic banks}

The Iraqi government has been providing all facilities to support governmental and private banks. Despite the large number of Islamic banks in Iraq, with very high capital, the Iraqi government owns only one Islamic bank. There are a set of challenges that are imposed on Islamic banks, including those related to the general climate, the stability of the state, the rule of law, and the structure of the Islamic banks themselves, in terms of the need to provide trained and qualified personal to have a good position in the market, and to invent new Islamic financing tools, as well as break free from the legal qualification cycle and taking advantage of the previous efforts from the Islamic Banking Council, on rules of accounting and Sharia audit. The challenge for Iraqi Islamic 
banks is to succeed in financing industrial and agricultural projects that improve their contribution to the economy, especially manufacturing industries with high added value.

The biggest challenge for Islamic banks is to bring financing to the poor and the middle class in light of the high rates of unemployment and poverty in Iraq, so that they can get out of the state of poverty to seriously contribute to economic activity. Small projects are among the most appropriate mechanisms in the economic situation of Iraq, but they require a greater spread. Islamic banking activities in the world were characterized by high rates of financing conventional activities through the Murabaha mechanism, which is undeniable, as Islamic banks are not charitable organizations, but rather they work using the funds of depositors.

But this does not prevent the Islamic banks from increasing the activities of other financing tools such as Musharaka (partnership), Istisna (financing manufacturing), ljara (leasing), and agriculture. These are tools that contribute greatly to the financing of small and medium enterprises, and are greatly needed by productive activities to develop the local economy.

Islamic banks ultimately remain part of the existing system, and are influenced by the general climate that prevails in the country, and in order to succeed in achieving its goals and facing the challenges we mentioned, the state must intensify its efforts to achieve political and security stability.

\section{The research methodology}

The research problem is that the number of depositors and investors in Iraqi Islamic banks is not increasing while applying Murabaha. Therefore, the question that reflects the essence of the problem is: Does the Murabaha standard currently applied by Islamic banks attract more investors and help increasing the number of depositors?

This research is especially important in Iraq because the environment in Iraq is considered diverse, because it contains conventional banks that apply IFRS and Islamic banks that apply Islamic standards AAOIFI, and the possibility of applying the best policies that help the investors make the right decision in choosing the suitable bank for their investing.

The method used depends on the questionnaire list, in order to identify Murabaha standard applied in the Islamic banks affects the number of depositors and investors, the questionnaire was designed by the researchers through from 10 Iraqi Islamic banks.

The researchers obtained the data for the study through a questionnaire that was distributed to 68 workers in the field of Islamic banks, but the researchers received 52 responses from several Islamic banks. The questionnaire used one axis: The impact of Murabaha standard in Islamic banks on the number's depositors and investors. This contains 13 questions.

The questionnaires were distributed to 10 Iraqi Islamic banks. Five-points Likert scale was used to measure analyse and interpret the opinions of the research sample. The five weight levels assigned to the responses were (1) do not know, (2) strongly disagree, (3) disagree, (4) agree, and (5) strongly agree to measure the degree of agreement (disagreement) of the respondents, as shown in Table 1.

Each interval was calculated by dividing $100 / 5$ and then the outcome 80 was added to the first point (1) of the scale and so on for the other points. The arithmetic mean was used to analyse the result, so if the mean was say 3.6, the result would be located in the category description "agree". To interpret this result the percentage analysis was also used by multiplying the result obtained 3.6 by 20 which means that $72 \%$ of the respondents to the questionnaire agree about the paragraph under study.

On the other hand, the researchers were able to meet and ask the responders online questions relating to their opinions. Because of the COVID-19 pandemic, it was very hard to reach them.

The researchers relied on the reasons below in choosing the banks:

1. Banks registered in Iraqi Central Bank.

2. Banks having a license or permit from the Central Bank of Iraq to practice banking.

3. The size of the capital and the size of the bank activities. 
The following table is the Islamic banks that have been used for the questionnaire.

Table 1. Islamic banks

\begin{tabular}{|c|l|c|c|c|}
\hline No. & \multicolumn{1}{|c|}{ Bank's name } & $\begin{array}{c}\text { Year } \\
\text { established }\end{array}$ & $\begin{array}{c}\text { No. } \\
\text { of branches }\end{array}$ & $\begin{array}{c}\text { Capital } \\
\text { in USD millions }\end{array}$ \\
\hline 1 & Elaf Islamic Bank & 2001 & 15 & 210 \\
\hline 2 & $\begin{array}{l}\text { Iraqi Islamic Bank for Investment } \\
\text { and Development }\end{array}$ & 1992 & 14 & 210 \\
\hline 3 & $\begin{array}{l}\text { Kurdistan International Bank } \\
\text { for Investment and Development }\end{array}$ & 2005 & 6 & 336 \\
\hline 4 & National Islamic Bank & 2005 & 10 & 211 \\
\hline 5 & $\begin{array}{l}\text { Islamic Cooperation Investment } \\
\text { Bank }\end{array}$ & 2006 & 8 & 210 \\
\hline 6 & $\begin{array}{l}\text { World Islamic Bank for Investment } \\
\text { and Finance }\end{array}$ & 2016 & 6 & 210 \\
\hline 7 & $\begin{array}{l}\text { Al-Janoob Islamic Bank for Investment } \\
\text { and Finance }\end{array}$ & 2009 & 4 & 210 \\
\hline 8 & Iraq Noor Islamic Bank & 2009 & 210 \\
\hline 9 & $\begin{array}{l}\text { Al-Qabidh Islamic Bank for Finance } \\
\text { and Investment }\end{array}$ & 2008 & 210 \\
\hline 10 & $\begin{array}{l}\text { Al-Qurtas Islamic Bank for Investment } \\
\text { and Finance }\end{array}$ & 2013 & 210 \\
\hline
\end{tabular}

Source: Contribution of researchers.

The banks above were used for the questionnaire. Some of the banks are new established for that and they have a smaller number of branches, others have many branches and located in Baghdad and other cities in Iraq.

This section presents a description of the main characteristics of the respondents to the questionnaire such as job title, gender, age, scientific qualifications, specialization, and the training programs taken by the respondents.

Table 2. Job title of the respondents to the questionnaire

\begin{tabular}{|l|c|c|}
\hline \multicolumn{1}{|c|}{ Job title } & Frequency & Percent \\
\hline Chief accountant & 16 & 30.1 \\
\hline Accountant & 24 & 65.8 \\
\hline Auditor & 5 & 1.6 \\
\hline Credit official & 7 & 2.5 \\
\hline Total & $\mathbf{5 2}$ & $\mathbf{1 0 0 . 0}$ \\
\hline
\end{tabular}

Source: Contribution of researchers.

The result indicated that the respondents possessed experience that was adequate to understand the paragraphs of the questionnaire and answer them accurately. 
Table 3. Gender of the respondents to the questionnaire

\begin{tabular}{|l|c|c|}
\hline \multicolumn{1}{|c|}{ Gender } & Frequency & Percent \\
\hline Male & 33 & 58.7 \\
\hline Female & 19 & 41.3 \\
\hline Total & $\mathbf{5 2}$ & $\mathbf{1 0 0 . 0}$ \\
\hline
\end{tabular}

Source: Contribution of researchers.

The result indicated that the banks relied on males more than females to occupy the leading accounting, auditing and credit official positions to implement the financial and accounting tasks.

\section{P Results and discussion}

Table 4 shows the views of research sample respondents on the fourth axis of the questionnaire: "Murabaha standard applied in the Islamic banks affects the number of depositors and investors". This axis contains 13 paragraphs. The most important of them are as follows:

1. The majority of the respondents, namely $81.9 \%$, agree on the content of paragraph 1 . However, $11.6 \%$ of the respondents disagree about it. This is confirmed by the arithmetic mean 4.12 , the standard deviation 1.083 and the coefficient of variation 0.26 , which represents a proportion of low dispersion. This result indicates that there is obvious agreement that the Central Bank of Iraq is conducting effective monitoring to ensure the commitment of Islamic banks to disclose the accounting policies used regarding the profit rate that they earn from depositors according to Murabaha contract, as is the case in the non-Islamic bank that applies IFRS.

2. Approximately three quarters, namely $74.9 \%$, of the respondents agree on the content of paragraph 7 . However, $18.1 \%$ of the respondents disagree about it. This is confirmed by the arithmetic mean 3.87, the standard deviation 1.155 and the coefficient of variation 0.30 , which represents a proportion of low dispersion. This result indicates that there is high agreement that hiring trained human resources to implement Murabaha in Islamic banks contributes to increasing the number of depositors and investors.

3. More than two thirds, $71.6 \%$ more precisely, of the respondents agree on the content of paragraph 5 . On the other hand, $20 \%$ of the respondents disagree about it. This is confirmed by the arithmetic mean 3.80, the standard deviation 1.197 and the coefficient of variation 0.32, which represents a proportion of low dispersion. This result indicates that there is obvious agreement that Islamic banks study the extent of depositors and investors' appetite when presenting the results of applying Murabaha standard.

4. $72.2 \%$ of the respondents agree on the content of paragraph 6 . Nevertheless, $17.4 \%$ of the respondents disagree about this paragraph. This is confirmed by the arithmetic mean 3.79, the standard deviation 1.294 and the coefficient of variation 0.34 , which represents a proportion of low dispersion. This result indicates that Islamic banks disclose the accounting policies for determining the annual interest rate (returns) for depositors that they earn when regulating Murabaha contracts.

5. Approximately three quarters, about $74.8 \%$, of the respondents agree on the content of paragraph 11 that. However, $16.2 \%$ of the respondents disagree about it. This is confirmed by the arithmetic mean 3.78 , the standard deviation 1.186 and the coefficient of variation 0.31 , which represents a proportion of low dispersion. This result indicates that a high percentage of the respondents agree that Islamic banks disclose the accounting policies for determining the annual interest rate (returns) for depositors that they earn when regulating Murabaha contracts.

6. More than two thirds, namely $72.9 \%$, of the respondents agree on the content of paragraph 2 that. On the other hand, $18.1 \%$ of the respondents disagree about it. This is confirmed by the arithmetic mean 3.75 , the standard deviation 1.164 and the coefficient of variation 0.31 , which represents a proportion of low dispersion. This result indicates that a high percentage of the respondents agree that the Central Bank of Iraq is conducting effective oversight to emphasize the need to obligate Islamic banks to implement IFRS in their annual reports. 
Table 4. The view of the respondents of the questionnaire (applying Murabaha increases the number of Islamic banks depositors)

\begin{tabular}{|c|c|c|c|c|c|c|c|c|c|c|c|c|c|c|c|c|}
\hline \multirow{2}{*}{ No. } & \multicolumn{2}{|c|}{ 일ำ } & \multicolumn{2}{|c|}{ 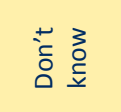 } & \multicolumn{2}{|c|}{ 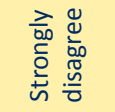 } & \multicolumn{2}{|c|}{ 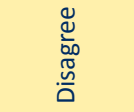 } & \multicolumn{2}{|c|}{ 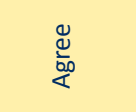 } & \multicolumn{2}{|c|}{ 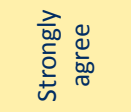 } & \multirow{2}{*}{ 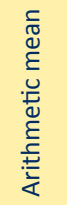 } & \multirow{2}{*}{ 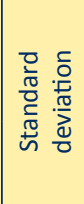 } & \multirow{2}{*}{ 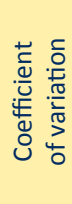 } & \multirow{2}{*}{ 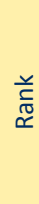 } \\
\hline & 这 & ১ீ & 这 & dீ & 这 & வீ & 这 & dீ & $\begin{array}{l}\dot{\Phi} \\
\dot{\Phi}\end{array}$ & ১゚ & 这 & ১ீ & & & & \\
\hline $\begin{array}{l}\text { 1. The Central Bank of Iraq is conducting } \\
\text { effective monitoring to ensure the } \\
\text { commitment of Islamic banks to disclose } \\
\text { the accounting policies used regarding the } \\
\text { profit rate that they earn from depositors } \\
\text { according to Murabaha contract. }\end{array}$ & - & - & 10 & 6.5 & 2 & 1.3 & 16 & 10.3 & 58 & 37.4 & 69 & 44.5 & 4.12 & 1.083 & 0.26 & 1 \\
\hline $\begin{array}{l}\text { 2. The Central Bank of Iraq is conducting } \\
\text { effective oversight to emphasize the need } \\
\text { to obligate Islamic banks to implement } \\
\text { the IFRSs in their annual reports. }\end{array}$ & 1 & 0.6 & 13 & 8.4 & 6 & 3.9 & 22 & 14.2 & 74 & 47.7 & 39 & 25.2 & 3.75 & 1.164 & 0.31 & 6 \\
\hline $\begin{array}{l}\text { 3. Islamic banks disclose the accounting } \\
\text { policies related to the mechanism } \\
\text { of distributing the returns of banking } \\
\text { operations to depositors' accounts } \\
\text { according to Murabaha contract. }\end{array}$ & 1 & 0.6 & 12 & 7.7 & 6 & 3.9 & 23 & 14.8 & 77 & 49.7 & 36 & 23.2 & 3.75 & 1.132 & 0.30 & 7 \\
\hline $\begin{array}{l}\text { 4. Islamic banks disclose accounting policies } \\
\text { related to the application of the IFRSs } \\
\text { in their annual financial statement. }\end{array}$ & 4 & 2.6 & 17 & 11.0 & 4 & 2.6 & 34 & 21.9 & 59 & 38.1 & 37 & 23.9 & 3.54 & 1.325 & 0.37 & 17 \\
\hline $\begin{array}{l}\text { 5. Islamic banks study the extent of depositors } \\
\text { and investors' appetite when presenting } \\
\text { the results of applying Murabaha. }\end{array}$ & 2 & 1.3 & 11 & 7.1 & 6 & 3.9 & 25 & 16.1 & 64 & 41.3 & 47 & 30.3 & 3.80 & 1.197 & 0.32 & 3 \\
\hline $\begin{array}{l}\text { 6. Islamic banks disclose the accounting } \\
\text { policies for determining the annual interest } \\
\text { rate (returns) for depositors that they earn } \\
\text { when regulating Murabaha contract. }\end{array}$ & 3 & 1.9 & 13 & 8.4 & 7 & 4.5 & 20 & 12.9 & 60 & 38.7 & 52 & 33.5 & 3.79 & 1.294 & 0.34 & 4 \\
\hline $\begin{array}{l}\text { 7. Hiring trained human resources to } \\
\text { implement Murabaha standard in Islamic } \\
\text { banks contributes to increasing the number } \\
\text { of depositors and investors. }\end{array}$ & 1 & 0.6 & 10 & 6.5 & 8 & 5.2 & 20 & 12.9 & 66 & 42.6 & 50 & 32.3 & 3.87 & 1.155 & 0.30 & 2 \\
\hline $\begin{array}{l}\text { 8. Depositors and investors depend } \\
\text { on taking the decision to deposit in Islamic } \\
\text { banks on the application of Murabaha } \\
\text { and (adopted credit risk management } \\
\text { policy and procedures). }\end{array}$ & 2 & 1.3 & 20 & 12.9 & 5 & 3.2 & 19 & 12.3 & 59 & 38.1 & 50 & 32.3 & 3.70 & 1.365 & 0.37 & 10 \\
\hline $\begin{array}{l}\text { 9. The increase in the number of depositors } \\
\text { in Islamic banks is affected by the application } \\
\text { of Murabaha and (classification of financial } \\
\text { assets and liabilities that are subject } \\
\text { to losses). }\end{array}$ & 3 & 1.9 & 17 & 11.0 & 10 & 6.5 & 25 & 16.1 & 62 & 40.0 & 38 & 24.5 & 3.55 & 1.330 & 0.37 & 15 \\
\hline $\begin{array}{l}\text { 10. Customers' confidence in Islamic banks } \\
\text { increases when applying Murabaha } \\
\text { standard and (expected credit loss). }\end{array}$ & 3 & 1.9 & 12 & 7.7 & 4 & 2.6 & 26 & 16.8 & 66 & 42.6 & 44 & 28.4 & 3.75 & 1.229 & 0.33 & 8 \\
\hline $\begin{array}{l}\text { 11. Islamic banks disclose the accounting } \\
\text { policies for determining the annual interest } \\
\text { rate (returns) for depositors that they charge } \\
\text { when regulating Al-Murabaha contract. }\end{array}$ & 1 & 0.6 & 13 & 8.4 & 8 & 5.2 & 17 & 11.0 & 74 & 47.7 & 42 & 27.1 & 3.78 & 1.186 & 0.31 & 5 \\
\hline $\begin{array}{l}\text { 12. The annual interest (returns) is } \\
\text { determined in advance when Murabaha } \\
\text { contract is signed between Islamic banks } \\
\text { and customers. }\end{array}$ & 3 & 1.9 & 12 & 7.7 & 5 & 3.2 & 29 & 18.7 & 60 & 38.7 & 46 & 29.7 & 3.74 & 1.249 & 0.33 & 9 \\
\hline
\end{tabular}




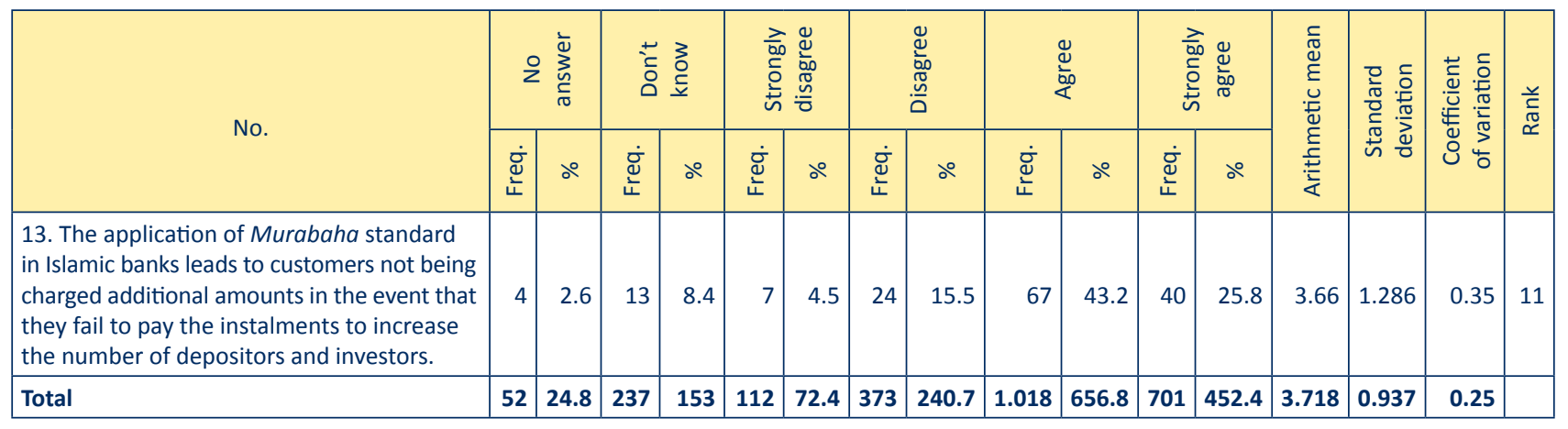

Source: Contribution of researchers.

The results show that the value of the general arithmetic mean for the fourth axis of the questionnaire was 3.718, which means that the opinions of the research sample tended to agree on its paragraphs with a standard deviation of 0.937 . Also, the coefficient of variation was 0.25 that represented a small dispersion ratio. Therefore, this result generally indicated that most respondents agree that Murabaha standard applied in the Islamic banks affects the number of depositors and investors.

Moreover, this result led us to reject the first null research hypothesis that Murabaha standard applied in the Islamic banks do not affect the number of depositors and investors, and accept the alternative hypothesis that "Murabaha standard applied in the Islamic banks affect the number of depositors and investors". This result is also supported by the two-way Friedman test. The test statistics are: the sample size $\mathrm{N}=155$, Chi-square $=$ 52.440 , degree of freedom $=16$, and significance level $=0,000$ which was less than the calculated significance level $\alpha \backslash 2=0.025$.

\section{P Conclusions}

These studies agreed on the mandatorily adopt of AAOIFI in Islamic institutions and especially Islamic banks, according to Islamic law Sharia.

We have shown what are the advantages and disadvantages for AAOIFI standards, the study has found that Islamic accounting standards are general they are not classified in groups and do not cover all aspects of accounting.

Murabaha is the most commonly used contract in Islamic banking. It's a contract between the clients and the bank to purchase an asset and sell it at a disclosed mark-up. The bank's profit is represented by that mark-up, and the reward for the risk inherent in the financing; in a case where the customers refuse to buy the product, the bank bears the loss. The main activities of an Islamic bank are based on the application of Islamic Sharia rules and exclude any type of interest from transactions, while the activities of the conventional banks are based on interest.

Islamic banks have become more realistic and economic thinking entities, and they have formed a tangible and effective reality to solve many economic and social problems that caused societies to suffer in Muslim and non-Muslim countries.

The researchers received 52 responses from 10 Islamic banks and used Cronbach's Alpha for analysing 13 questions in the questionnaire. The result led us to reject the first null research assumption that Murabaha standard applied in the Islamic banks does not affect the number of depositors and investors.

The researchers' opinion is that the Islamic banking is a growing and interesting phenomenon that received additional attention after the 2008 financial crisis, when people lost confidence in conventional banks. However, Islamic banking is similar to conventional banking, as it copies the traditional model of conventional banks, but it is more specific with Islamic principles, knowing that, there are cases in which Islamic banks perform better than conventional banks. It depends on the customer's choice to have an economic incentive or a religious commitment for choosing the bank. Even though Iraq is a country full of diverse sources to support the economy, it's currently relying on oil imports to finance the general budget. 


\section{○ Recommendations}

$\checkmark$ AAOIFI needs to take the knowledge from IFRS experiences as an accounting standard-setter.

$\checkmark$ Urging graduate students in Iraqi universities to continue preparing scientific research in this field of applying international standards in Islamic banks.

\section{References}

1. Ahmed, H. (2014), Islamic Banking and Shari'ah Compliance: A Product Development Perspective, Journal of Islamic Finance, Vol. 3, No. 2, pp. 15-29.

2. Al-Askar, S.R. (2005), Client and Employee Perceptions of Islamic Banking in Saudi Arabia, Durham Theses, Durham University.

3. Al-Duhaidahawi, H.M.K., Zhang, J., Abdulreza, M.S., Harjan, S.A., Shah, S.S.H. (2019), The Role of Financial Inclusion and Competitive Advantage: Evidence from Iraqi Islamic Banks, International Journal of Economics and Financial Issues, Vol. 9, No. 3, pp. 193-199.

4. Ben Arab, M., Elmelki, A. (2008), Managing Risks and Liquidity in an Interest Free Banking Framework: The Case of the Islamic Banks, International Journal of Business and Management, Vol. 3, No. 9, pp. 80-95.

5. Cornett, M.M., Guo, L., Khaksari, S., Tehranian, H. (2010), The Impact of State Ownership on Performance Differences in Privately-Owned Versus State-Owned Banks: An International Comparison, Journal of Financial Intermediation, Vol. 19, No. 1, pp. 74-94.

6. Elgattani, T. (2018), AAOIFI Governance Disclosure in Islamic Banks: Its Determinants and Impact on Performance, Doctoral Thesis, University of Portsmouth.

7. Farooq, M.O. (2007), Partnership, Equity-Financing and Islamic Finance: Whither Profit-Loss Sharing, Review of Islamic Economics, Vol. 11, Special Issue, pp. 67-88.

8. Ibrahim, A.M., Yahya, S.B., Abdalla, Y.A. (2003), Examining the Influence of the Characteristics of Islamic Banks and Shariah Supervisory Board on the Level of Social Responsibility Disclosure: A Review from Sudan, International Journal of Business and Innovation, Vol. 2, No. 3, pp. 23-51.

9. Iqbal, Z., Mirakhor, A. (2011), The Islamic Financial System, in An Introduction to Islamic Finance: Theory and Practice, Second Edition, pp. 113-136.

10. Kam, V. (1990), Review of Arithmetic, Geometry, and Proportions.

11. Maurer, B. (2010), Form Versus Substance: AAOIFI Projects and Islamic Fundamentals in the Case of Sukuk, Journal of Islamic Accounting and Business Research, Vol. 1, No. 1, pp. 32-41.

12. Muhammad (2002), Pengantar Akuntansi Syariah, Salemba Empat, Jakarta.

13. Nguyen, Q.K. (2021), Oversight of Bank Risk-Taking by Audit Committees and Sharia Committees: Conventional vs Islamic Banks, Heliyon, Vol. 7, No. 8.

14. Rahman, A., Rahim, A. (2007), Islamic Microfinance: A Missing Component in Islamic Banking (Islamic Economics: Theoretical and Practical Perspectives in a Global Context), Kyoto Bulletin of Islamic Area Studies, Vol. 1, No. 2, pp. 38-53.

15. Rahman, A., Rahim, A. (2007), Pre-Requisites for Effective Integration of Zakat into Mainstream Islamic Financial System in Malaysia, Islamic Economic Studies, Vol. 14, No. 1-2, pp. 91-107.

16. Usmani, M.T. (2010), Present Financial Crisis. Causes and Remedies from Islamic Perspective.

17. AAOIFI (2002), https://.aaoifi.com.

18. AAOIFI (2008), https://.aaoifi.com.

19. Al Qur'an Chapter 2: Sūrat Al-Baqarah (The Cow), https://corpus.quran.com.

20. Central Bank of Iraq (2020), The Edition, https://www.cbi.iq. 